\title{
Inactivation of microbiota from urban wastewater by single and sequential electrocoagulation and electro-Fenton treatments
}

\author{
Eduard Anfruns-Estrada ${ }^{\mathrm{a}}$, Carmina Bruguera-Casamada ${ }^{\mathrm{a}}$, Humbert Salvadó ${ }^{\mathrm{a}, \mathrm{b}}$, Enric Brillas ${ }^{\mathrm{c}}$, Ignasi Sirés ${ }^{\mathrm{c}, *}$, \\ Rosa M. Araujo ${ }^{\text {a } * *}$ \\ ${ }^{a}$ Sec. Microbiologia, Virologia i Biotecnologia, Departament de Genètica, Microbiologia i Estadística, Facultat de Biologia, Universitat de Barcelona, Avinguda Diagonal 643, \\ 08028 Barcelona, Spain

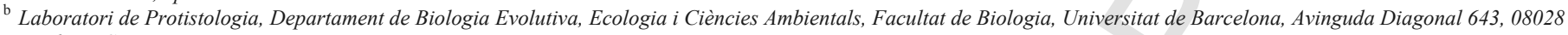 \\ Barcelona, Spain \\ ' Laboratori d'Electroquímica dels Materials i del Medi Ambient, Departament de Química Física, Facultat de Química, Universitat de Barcelona, Martí i Franquès 1-11, 08028 \\ Barcelona, Spain
}

\section{A R T I C L E I N F O}

\section{Article history:}

Received 24 July 2017

Received in revised form 27 September 2017

Accepted 28 September 2017

Available online $\mathrm{xxx}$

Keywords:

Indicator bacteria

Electrochemical disinfection

Electrocoagulation

Electro-Fenton

Sequential water treatment

Urban wastewater

\begin{abstract}
A B S T R A C T
This work aims at comparing the ability of two kinds of electrochemical technologies, namely electrocoagulation (EC) and electro-Fenton (EF), to disinfect primary and secondary effluents from municipal wastewater treatment plants. Heterotrophic bacteria, Escherichia coli, enterococci, Clostridium perfringens spores, somatic coliphages and eukaryotes (amoebae, flagellates, ciliates and metazoa) were tested as indicator microorganisms. EC with an $\mathrm{Fe} / \mathrm{Fe}$ cell at $200 \mathrm{~A} \mathrm{~m}^{-2}$ and natural $\mathrm{pH}$ allowed $>5 \log$ unit removal of $E$. coli and final concentration below 1 bacteria $\mathrm{mL}^{-1}$ of coliphages and eukaryotes from both effluents in ca. 60 min, whereas heterotrophic bacteria, enterococci and spores were more resistant. A larger removal was obtained for the primary effluent, probably because the flocs remove higher amount of total organic carbon (TOC), entrapping more easily the microbiota. EF with a boron-doped diamond (BDD) anode and an air-diffusion cathode that produces $\mathrm{H}_{2} \mathrm{O}_{2}$ on site was first performed at $\mathrm{pH}$ 3.0, with large or even total inactivation of microorganisms within $30 \mathrm{~min}$. A more effective microorganism removal was attained as compared to EC thanks to ${ }^{\circ} \mathrm{OH}$ formed from Fenton's reaction. A quicker disinfection was observed for the secondary effluent owing to its lower TOC content, allowing the attack of greater quantities of electrogenerated oxidants on microorganisms. Wastewater disinfection by EF was also feasible at natural $\mathrm{pH}(\sim 7)$, showing similar abatement of active microorganisms as a result of the synergistic action of generated oxidants like active chlorine and coagulation with iron hydroxides. A sequential EC/EF treatment (30 min each) was more effective for a combined decontamination and disinfection of urban wastewater.
\end{abstract}

\section{Introduction}

Wastewater disposal through direct discharge into the aquatic environment entails potential risks for humans, animals and ecosystems due to the presence of chemical and microbiological contaminants. Among the challenges and priorities to 2030, the Sustainable Development Goals of United Nations (2015) include the improvement of water quality by eliminating dumping and minimizing release of hazardous chemicals and materials, halving the proportion of untreated wastewater and considerably increasing safe reuse globally. Nowadays, municipal wastewater treatment plants (WWTPs) substantially reduce the contaminants from influents, yielding effluents that are discharged to rivers or seas. However, water scarcity along with increasing population and intensification of agricultural and industrial activities have triggered the development of efficient methods to ob-

\footnotetext{
* Corresponding author.

** Corresponding author.

Email addresses: i.sires@ub.edu (I. Sirés); raraujo@ub.edu (R.M. Araujo)
}

tain safe reclaimed water for crop irrigation, aquifer recharge and drinking water production (Fernandez-Cassi et al., 2016).

Bacteria, viruses, protozoa and metazoa have been detected in urban wastewater and many of them are pathogens that cause diseases to living beings. These microorganisms are biologically and structurally different and hence, their inactivation depends on the applied treatment (Hijnen et al., 2006; Cervero-Aragó et al., 2015). The microbiological quality of treated water is normally assessed with indicators like fecal coliforms, but its validity to ensure the effectiveness of water treatment over viruses, protozoa or non-fecal bacteria is rather arguable (Ashbolt et al., 2001; Figueras and Borrego, 2010; Payment and Locas, 2011). Other indicators such as heterotrophic bacteria, enterococci, bacteriophages and adenovirus have been also considered. For example, Agulló-Barceló et al. (2013) proposed the spores of sulfite-reducing clostridia as indicators of Cryptosporidium total oocysts. Quality requirements of reclaimed water are usually regulated by national environmental protection agencies. In Spain, for example, 100 colony-forming unit (CFU) per $100 \mathrm{~mL}$ is the maximal content of Escherichia coli permitted for reuse in food crops, whereas 
$200 \mathrm{CFU}$ per $100 \mathrm{~mL}$ is the limit for urban unrestricted reuse (Real Decreto 1620, 7 December 2007).

Urban effluents reaching WWTPs are typically conveyed through a multistep process comprising: (i) a primary treatment to remove solid material, (ii) a secondary treatment to minimize the content of organic matter (OM) and microorganisms and (iii) a tertiary process for disinfection and destruction of trace organics. Often, the secondary treatment consists of a biological method that requires large areas and long residence times, whereas the tertiary treatment involves chlorination or UV irradiation (Martínez-Huitle and Brillas, 2008; Montemayor et al., 2008; Souza et al., 2013). Electrochemical disinfection can be an interesting alternative because it is more eco-friendly and cost-effective (Ghernaout and Ghernaout, 2010), being electrocoagulation (EC) and electro-Fenton (EF) two of the most promising technologies for this purpose.

EC involves the in situ generation of coagulants by electrochemical oxidation of a sacrificial anode (iron or aluminum) in an undivided cell. The released metal ions are further transformed into hydroxides that neutralize charges or act as sweep flocs with large surface areas and hence, they foster their aggregation or precipitate as a sludge, adsorbing the dissolved pollutants (Ghernaout and Ghernaout, 2012; Ghernaout, 2013). Using $\mathrm{Fe}$ as the anode, for example, $\mathrm{Fe}^{2+}$ is formed from Reaction (1) and in the presence of dissolved $\mathrm{O}_{2}$ gas is converted into $\mathrm{Fe}$ (III) from the global Reaction (2) (Barrera-Díaz et al., 2014; Brillas and Martínez-Huitle, 2015). $\mathrm{H}_{2}$ is formed at the cathode from water reduction by Reaction (3). $\mathrm{Fe}(\mathrm{OH})_{2}(\mathrm{~s})$ at $\mathrm{pH}>5.5$ and $\mathrm{Fe}(\mathrm{OH})_{3}(\mathrm{~s})$ from $\mathrm{pH}>1.0$ act as: (1) coagulants that remove particles by surface complexation or electrostatic attraction and (2) flocculants that eliminate particles by sweep flocculation (Ghernaout and Ghernaout, 2012).

$$
\mathrm{Fe} \rightarrow \mathrm{Fe}^{2+}+2 \mathrm{e}^{-}
$$

$4 \mathrm{Fe}+10 \mathrm{H}_{2} \mathrm{O}+\mathrm{O}_{2}(\mathrm{~g}) \rightarrow 4 \mathrm{Fe}(\mathrm{OH})_{3}(\mathrm{~s})+4 \mathrm{H}_{2}(\mathrm{~g})$

$2 \mathrm{H}_{2} \mathrm{O}+2 \mathrm{e}^{-} \rightarrow 2 \mathrm{OH}^{-}+\mathrm{H}_{2}(\mathrm{~g})$

The EF process is based on the electrogeneration of $\mathrm{H}_{2} \mathrm{O}_{2}$ by two-electron reduction of $\mathrm{O}_{2}$ gas at a carbonaceous cathode like a carbon-polytetrafluoroethylene (PTFE) air-diffusion electrode (Sirés et al., 2014; Moreira et al., 2017), via Reaction (4). This method is very effective when a small quantity of $\mathrm{Fe}^{2+}(<1 \mathrm{mM})$ is added to the effluent to react with $\mathrm{H}_{2} \mathrm{O}_{2}$ yielding $\mathrm{Fe}^{3+}$ and ${ }^{\circ} \mathrm{OH}$ from Fenton's Reaction (5) at optimum pH ca. 3 (El-Ghenymy et al., 2015; Thiam et al., $2015,2016)$. ${ }^{\circ} \mathrm{OH}$ is a very strong oxidant with ability to mineralize most organics (Sirés et al., 2014). Additionally, in an undivided cell at high current, organics and microorganisms are also destroyed by physisorbed hydroxyl radical $\mathrm{M}\left({ }^{\circ} \mathrm{OH}\right)$ produced from water oxidation at the surface of a large $\mathrm{O}_{2}$-overvoltage anode $\mathrm{M}$ such as boron-doped diamond (BDD) by Reaction (6). BDD thin-film electrodes are the best anodes for EF due to the high activity of BDD( $\left.{ }^{\circ} \mathrm{OH}\right)$ (El-Ghenymy et al., 2015; Bruguera-Casamada et al., 2016, 2017).

$$
\begin{aligned}
& \mathrm{O}_{2}(\mathrm{~g})+2 \mathrm{H}^{+}+2 \mathrm{e}^{-} \rightarrow \mathrm{H}_{2} \mathrm{O}_{2} \\
& \mathrm{Fe}^{2+}+\mathrm{H}_{2} \mathrm{O}_{2} \rightarrow \mathrm{Fe}^{3+}+{ }^{\cdot} \mathrm{OH}+\mathrm{OH}
\end{aligned}
$$

$\mathrm{M}+\mathrm{H}_{2} \mathrm{O} \rightarrow \mathrm{M}\left({ }^{\circ} \mathrm{OH}\right)+\mathrm{H}^{+}+\mathrm{e}^{-}$
Urban wastewater contains a large amount of $\mathrm{SO}_{4}{ }^{2-}$ and $\mathrm{Cl}^{-}$ (Thiam et al., 2016). These ions can be oxidized at the BDD anode to yield other oxidants like peroxodisulfate $\left(\mathrm{S}_{2} \mathrm{O}_{8}{ }^{2-}\right)$ from Reaction (7) and active chlorine $\left(\mathrm{Cl}_{2} / \mathrm{HClO} / \mathrm{ClO}^{-}\right)$from Reactions (8)-(10) (Thiam et al., 2015; Steter et al., 2016). Recent work has shown that active chlorine can be formed during EC treatments (Ghernaout et al., 2011; Bocos et al., 2016), which may cause the formation of toxic disinfection by-products (DBPs).

$$
\begin{aligned}
& 2 \mathrm{SO}_{4}^{2-} \rightarrow \mathrm{S}_{2} \mathrm{O}_{8}^{2-}+2 \mathrm{e}^{-} \\
& 2 \mathrm{Cl}^{-} \rightarrow \mathrm{Cl}_{2}(\mathrm{aq})+2 \mathrm{e}^{-} \\
& \mathrm{Cl}_{2}(\mathrm{aq})+\mathrm{H}_{2} \mathrm{O} \rightarrow \mathrm{HClO}+\mathrm{Cl}^{-}+\mathrm{H}^{+} \\
& \mathrm{HClO} \leftrightarrows \mathrm{ClO}^{-}+\mathrm{H}^{+} \mathrm{p} K_{\mathrm{a}}=7.56
\end{aligned}
$$

Several authors have applied $\mathrm{EC}$ with $\mathrm{Fe}$ or $\mathrm{Al}$ anodes to disinfect urban effluents from WWTPs, finding a total removal ( $>99.99 \%)$ of $E$. coli (Ghernaout et al., 2008; Cotillas et al., 2013; Llanos et al., 2017), total coliforms (Elazzouzi et al., 2017; Makwana and Ahammed, 2017) or S. aureus (Valero et al., 2017). Durán Moreno et al. (2004) also found an overall removal of total coliforms, E. coli, Shigella and Salmonella sp. from municipal wastewater at the end of EC with $\mathrm{H}_{2} \mathrm{O}_{2}$ addition, so-called EF by these authors. However, an exhaustive study on the evolution of urban wastewater microbiota during EC or EF has not been reported so far. Furthermore, the feasibility of a sequential $\mathrm{EC} / \mathrm{EF}$ treatment has only been explored to remove organic matter, turbidity and total suspended solids from synthetic and urban wastewater (Daghrir and Drogui, 2013; Thiam et al., 2014).

This paper aims to assess the ability of $\mathrm{EC}$ with an $\mathrm{Fe} / \mathrm{Fe}$ cell, EF with a BDD/air-diffusion cell and a sequential EC/EF process to inactivate microorganisms contained in real urban wastewater collected from primary and secondary WWTP clarifiers. Considering the microbiological complexity of both effluents, heterotrophic bacteria, E. coli, enterococci, C. perfringens spores, somatic coliphages and eukaryotes were selected as indicators. The decay of microorganism content over electrolysis time was determined at constant current density $(j)$ to clarify if the sequential EC/EF treatment is potentially beneficial to disinfect urban wastewater.

\section{Materials and methods}

\subsection{Urban wastewater}

Urban effluents were obtained from a WWTP located in Reus (Spain). Several sets of fresh samples were collected on different days from the primary treatment effluent as well as from the secondary treatment (i.e., activated sludge) effluent. These effluents were selected to assess the influence of different OM content on microorganism abatement in the EC, EF and sequential EC/EF processes tested. They were introduced in sterile containers, transported to the laboratory in larger isothermal containers at $4{ }^{\circ} \mathrm{C}$, microbiologically characterized within $24-48 \mathrm{~h}$ after collection and stored at $4^{\circ} \mathrm{C}$. Tests revealed the presence of bacteria, bacteriophages, spores and protozoa. To ensure the detection of protozoa, the secondary effluent sample was doped with $5 \%$ of the treatment plant 
sludge, which did not alter substantially the number of bacteria and bacteriophages.

\subsection{Microbial enumeration}

In EC, microbiota concentrations were determined after separation of the sludge formed, whereas no filtration was required in EF. Heterotrophic bacteria were quantified upon 10-fold dilution with $1 / 4$-strength Ringer's solution and culture by duplicate on Plate Count Agar (PCA) from Scharlab (Spain) at $37^{\circ} \mathrm{C}$ for $48 \mathrm{~h}$ (Serrano-Suárez et al., 2013), according to ISO 9308-2:2012. The theoretical detec-

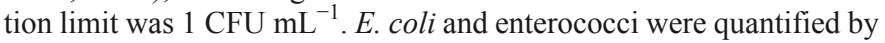
most probably number (MPN) using 4-methylumbelliferyl-beta- $d$-glucuronide (MUG)/EC and 4-methylumbelliferyl- $\beta$-D-glucopyranoside (MUD)/SF Kit 96-well microplates from Bio-Rad Laboratories, respectively, both incubated at $42{ }^{\circ} \mathrm{C}$ for $48 \mathrm{~h}$, following ISO 9308-2:2012. The theoretical detection limit was $0.35-1.35$ bacteria $\mathrm{mL}^{-1}$. Spores of Clostridium perfringens (sulfite-reducing clostridia) were quantified after heating the sample at $80^{\circ} \mathrm{C}$ for $10 \mathrm{~min}$, followed by mixing with liquefied sulphite polymyxin sulphadiazine (SPS) Agar from Scharlab. Samples were incubated at $44^{\circ} \mathrm{C}$ for $24 \mathrm{~h}$, following ISO 7939. The theoretical detection limit was 1 spore $\mathrm{mL}^{-1}$. Somatic coliphages were quantified by cell lysis using a double-layer counting method with $E$. coli WG5, according to ISO 10705-2. The theoretical detection limit was 1 lysis calve per $\mathrm{mL}$.

Eukaryotes were analyzed by microscopy using a Leitz Dialux20 microscope. Two Eppendorf tubes with $1 \mathrm{~mL}$ sample were centrifuged at $1500 \mathrm{rpm}$ for $10 \mathrm{~min}$. Supernatants were discharged and the pellets (about $200 \mu \mathrm{L}$ each) were analyzed by microscopy. Abundance of active protozoa (such as amoebae, flagellates and ciliates) and metazoa was counted from $100 \mu \mathrm{L}$ samples by successive $25 \mu \mathrm{L}$ replicates in vivo at $100 \times$ magnification. When small flagellates $(<20 \mu \mathrm{m})$ and amoebae $(<20 \mu \mathrm{m})$ were abundant enough, they were counted at $400 \times$ magnification and, for each replicate, 30 microscopic fields on the coverslip $(20 \mathrm{~mm} \times 20 \mathrm{~mm})$ were taken. The counts were carried out using well-homogenized samples. Protozoan species were identified at different levels: ciliates were determined as species level (Foissner et al., 1994; Curds et al., 2008), whereas flagellates (Lee et al., 2000) and amoebae (Page, 1988) were grouped according to their size and morphology. Note that the groups of amoebae cannot be considered as taxa since they might be composed of several amoebae belonging to diverse lineages (Page, 1988).

\subsection{Electrochemical systems}

The EC assays were carried out in an undivided cylindrical tank reactor containing $200 \mathrm{~mL}$ of primary or secondary effluent kept at $25^{\circ} \mathrm{C}$ thanks to a thermostatically-controlled water bath. The anode and cathode were $10 \mathrm{~cm}^{2}$ Fe plates separated $1 \mathrm{~cm}$. In these trials, a $j=200 \mathrm{~A} \mathrm{~m}^{-2}$ was always applied. The EF experiments were conducted in a similar undivided cell with $100 \mathrm{~mL}$ of each wastewater after addition of $0.25 \mathrm{mM} \mathrm{FeSO} 4 \cdot 7 \mathrm{H}_{2} \mathrm{O}$ ( $>99 \%$ purity, Sigma-Aldrich), except in EC/EF runs. The cell was equipped with a $3 \mathrm{~cm}^{2} \mathrm{BDD}$ thin-film electrode over $\mathrm{Si}$ substrate from NeoCoat (Le-Chaux-de-Fonds, Switzerland) and a $3 \mathrm{~cm}^{2}$ carbon-PTFE air-diffusion electrode from Sainergy Fuel Cell (Chenai, India), separated about $1 \mathrm{~cm}$. The cathode was mounted as described elsewhere (El-Ghenymy et al., 2015) and was fed with air flowing at $1 \mathrm{~L} \mathrm{~min}^{-1}$ to produce $\mathrm{H}_{2} \mathrm{O}_{2}$. A $j=333 \mathrm{~A} \mathrm{~m}^{-2}$ was employed for all the EF runs. The wastewater was always vigorously stirred at $800 \mathrm{rpm}$ with a magnetic PTFE bar. The constant current in all the electrolyses was provided by an Amel 2053 potentiostat-galvanostat, using a Demestres 601BR digital timeter for the direct measurement of the cell voltage. Before the EC assays, the Fe surfaces were mechanically abraded using $\mathrm{SiC}$ paper, followed by cleaning with $0.1 \mathrm{M} \mathrm{H}_{2} \mathrm{SO}_{4}$ solution and final ultrasonic cleaning in Milli-Q water. Before the EF runs, the BDD surface was cleaned and the air-diffusion cathode was activated by polarization in $0.050 \mathrm{M} \mathrm{Na}_{2} \mathrm{SO}_{4}$ at $j=1000 \mathrm{~A} \mathrm{~m}^{-2}$ for $180 \mathrm{~min}$.

After each trial, the cell was cleaned with a $\mathrm{H}_{2} \mathrm{O}_{2}: \mathrm{H}_{2} \mathrm{SO}_{4}$ mixture for $10 \mathrm{~min}$, rinsed with Milli-Q water and dried in an oven at $80^{\circ} \mathrm{C}$. The Fe and BDD electrodes were immersed in Milli-Q water at $100^{\circ} \mathrm{C}$ for $10 \mathrm{~min}$ and dried under an air stream. The air-diffusion cathode was cleaned with a $1: 3(\mathrm{v} / \mathrm{v}) \mathrm{H}_{2} \mathrm{O}: \mathrm{HCl}$ mixture and rinsed with Milli-Q water followed by air-drying. For $\mathrm{EF}$ at $\mathrm{pH} 3.0, \mathrm{HClO}_{4}$ was used to adjust the $\mathrm{pH}$ in order to maintain the content of reactive $\mathrm{SO}_{4}{ }^{2-}$ and $\mathrm{Cl}^{-}$ions in the urban effluents. Samples withdrawn from the treated effluents were adjusted to $\mathrm{pH}$ near 7 by adding $1 \mathrm{M} \mathrm{NaOH}$ solution to minimize the effect of low $\mathrm{pH}$ during microorganism culture. The $\mathrm{pH}$ was adjusted to about 7 with $1 \mathrm{M} \mathrm{H}_{2} \mathrm{SO}_{4}$ after the EC step prior to the sequential treatment with $\mathrm{EF}$.

\subsection{Analytical methods}

The solution $\mathrm{pH}$ was measured with a Crison GLP $22 \mathrm{pH}$-meter and the electrical conductance was determined with a Metrohm 644 conductometer. Total organic carbon (TOC) analysis of samples was carried out with a Shimadzu TOC-VCNS analyzer. Reproducible values with an accuracy of $\pm 1 \%$ were found by injecting $50 \mu \mathrm{L}$ aliquots, which were previously filtered with $0.45 \mu \mathrm{m}$ filters from Whatman, into the analyzer.

The inactivation profiles for all microorganisms were determined from the decay of their $\log \left(N_{\mathrm{t}} / N_{0}\right)$, where $N_{\mathrm{t}}$ and $N_{0}$ denote their concentration at time $t$ and 0 , respectively. The microorganism content is given as the mean value from two independent trials, and the graphs also show the error bars that account for a $95 \%$ confidence interval.

\section{Results and discussion}

\subsection{Electrocoagulation}

The EC assays were performed with $200 \mathrm{~mL}$ of the primary and secondary effluents using a stirred $\mathrm{Fe} / \mathrm{Fe}$ tank reactor at $j=200 \mathrm{~A} \mathrm{~m}^{-2}$ for $90 \mathrm{~min}$. The initial $\mathrm{pH}$ of $7.54 \pm 0.16$ rose continuously up to a final value of $9.08 \pm 0.27$, whereas the conductivity remained practically unchanged, varying between 2.50 and $2.04 \mathrm{mS} \mathrm{cm}^{-1}$.

Fig. 1a and $\mathrm{b}$ highlights an uneven disappearance of the different microorganisms during the treatment of both wastewater samples. Somatic coliphages were the less persistent organisms, being undetectable after $20 \mathrm{~min}$ in both matrices, followed by the eukaryotes, whose content decreased substantially at that time with total disappearance at $60 \mathrm{~min}$. In contrast, the concentration of heterotrophic bacteria decayed to $\sim 10^{3} \mathrm{CFU} \mathrm{mL}^{-1}$ in $90 \mathrm{~min}$, corresponding to a reduction of 3.66 and $2.81 \mathrm{log}$ units for the primary and secondary effluents, respectively. Fig. S1 reveals a quick removal of such bacteria in both matrices during the first 10 min of EC, followed by a slower concentration decay until the end of the electrolysis. A similar trend was found for all the other bacteria analyzed. In all cases, a larger content reduction was obtained for the primary effluent compared to the second one, probably because of its higher amount of microbiota and the presence of a larger amount of organic matter with ability to be coagulated and adsorb microorganisms. The removal process was usually stabilized after 30-40 min of electrolysis, whereupon no further microorganism abatement was achieved. 
a

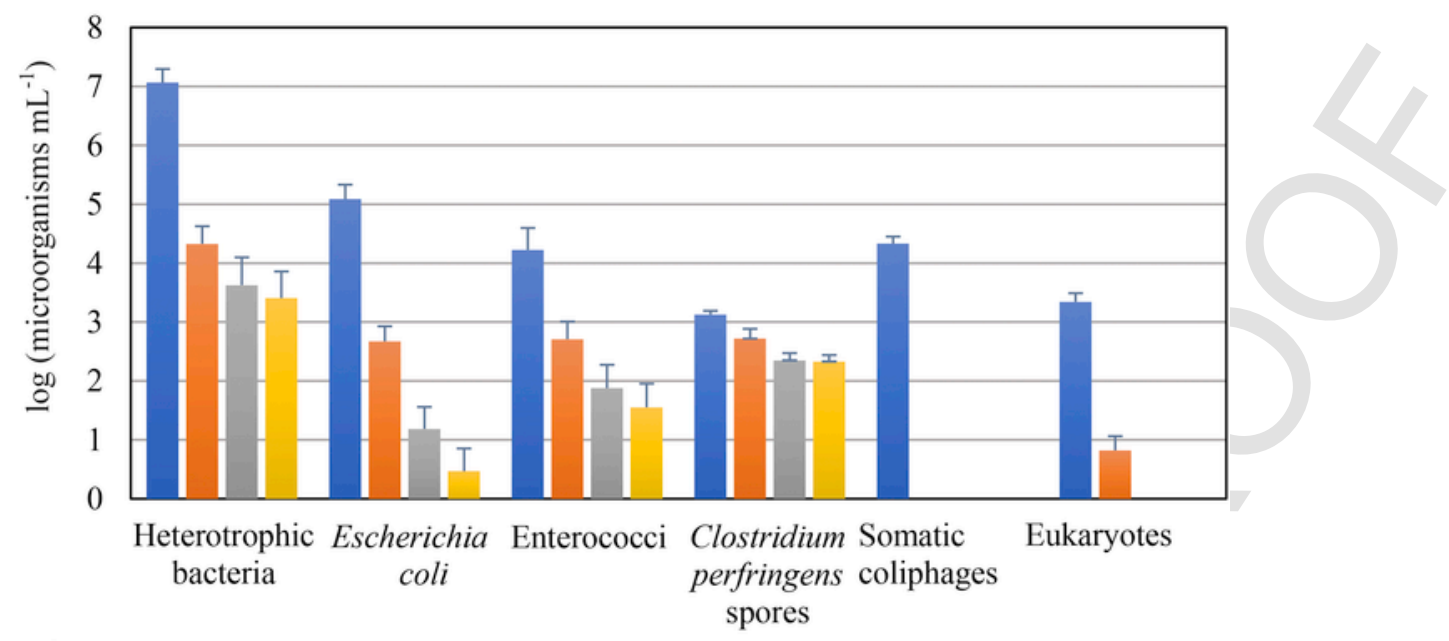

b

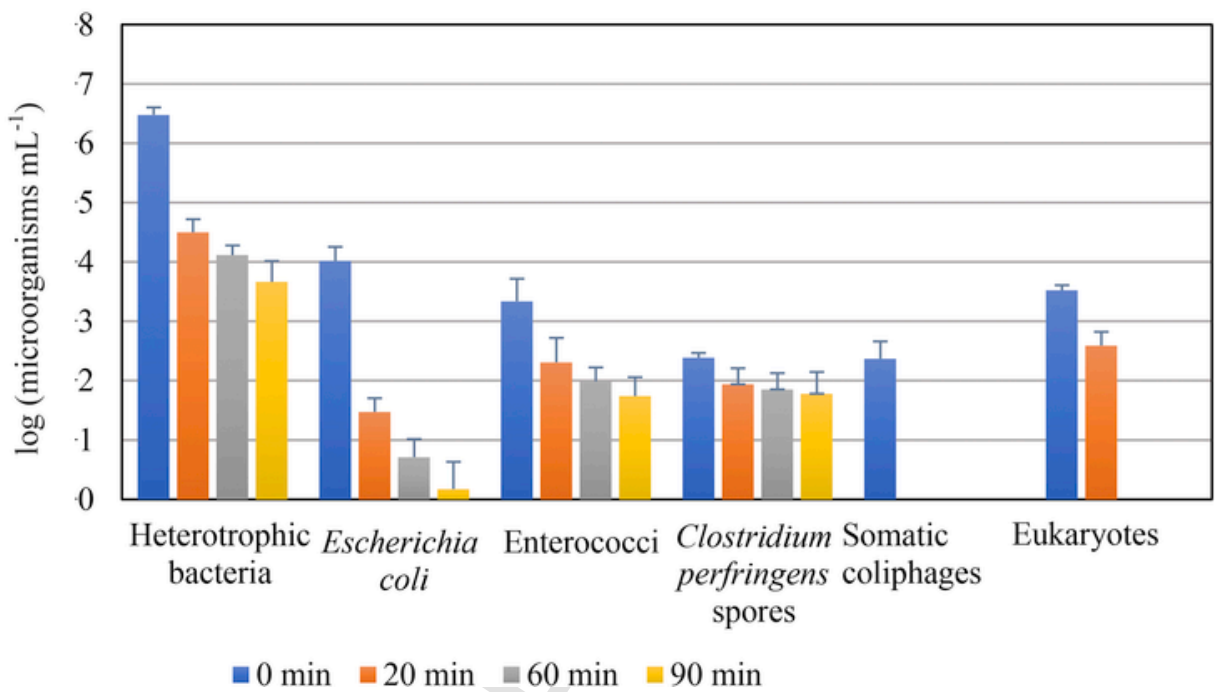

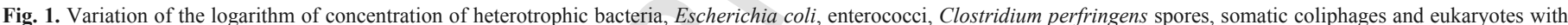

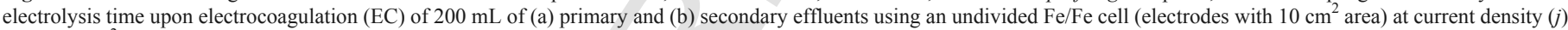
of $200 \mathrm{~A} \mathrm{~m}^{-2}$ and $25^{\circ} \mathrm{C}$.

On the other hand, almost complete abatement of $E$. coli was attained, with a strong reduction of $4.62 \mathrm{log}$ units in the primary effluent and $3.84 \log$ units in the secondary effluent. It was the less persistent bacterium to EC among those tested. Much poorer decay of 2.68 and $1.60 \log$ units in such media was found for enterococci. Worth noting, C. perfringens spores became the most resistant target, with a decay as low as 0.80 and $0.61 \log$ units in the primary and secondary effluents, respectively. Finally, the large influence of EC on the eukaryotic community, as depicted in Table 1, is also noticeable, with no apparent activity of all these microorganisms after $60 \mathrm{~min}$ of electrolysis. The presence of eukaryotes was somewhat longer when treating the secondary effluents. At $5 \mathrm{~min}$, only some flagellated volvocales could not be removed from the primary effluent, whereas all kinds of eukaryotes still remained in the second one despite their strong content drop. At $20 \mathrm{~min}$, only amoebae could not be abated substantially in the latter effluent.

Despite the large disappearance of all the microbiota under study, TOC content underwent a rather discrete removal for both kinds of wastewater upon EC treatment. Fig. 2 shows that TOC decayed $17.6 \mathrm{mg} \mathrm{L}^{-1}\left(24.6 \%\right.$ of the initial $\left.71.4 \mathrm{mg} \mathrm{L}^{-1}\right)$ for the primary effluent and $5.5 \mathrm{mg} \mathrm{L}^{-1}\left(35.2 \%\right.$ of the initial $\left.15.6 \mathrm{mg} \mathrm{L}^{-1}\right)$ for the secondary one. The relatively larger decontamination of the latter wastewater can be related to its smaller organic load, which is pre-eminently removed by precipitation over the $\mathrm{Fe}(\mathrm{OH})_{\mathrm{n}}$ flocs originated during the treatment at the same $j$ value.

Additional analyses were made with the sludge collected during the EC treatments, confirming that a small proportion of coagulated microorganisms were still active. This suggests their adhesion with encapsulation on the flocs formed, as recently reported by Delaire et al. (2016). The successful disinfection of sewage water samples is in accordance with the results obtained by other authors using EC with different anodes at other applied currents. For example, Ghernaout et al. (2008) described a large abatement of E. coli and algae from surface water with aluminum, stainless steel and common steel anodes. Bacteria removal in surface water (Ricordel et al., 2010) and in model solutions (Ricordel et al., 2014) using aluminum anode has 
Table 1

Time course of eukaryotic community (in microorganisms $\mathrm{mL}^{-1}$ ) during the treatment of primary and secondary effluents by electrocoagulation (EC) and electro-Fenton (EF). $\mathrm{EC}$ was carried out in an undivided $\mathrm{Fe} / \mathrm{Fe}$ cell with electrodes of $10 \mathrm{~cm}^{2}$ area at $j=200$ $\mathrm{A} \mathrm{m}^{-2}$, whereas EF was perforrmed at $\mathrm{pH} 3.0$ or close to 7 (natural $\mathrm{pH}$ ) using an undivided BDD/air-diffusion cell with electrodes of $3 \mathrm{~cm}^{2}$ area at $j=333 \mathrm{~A} \mathrm{~m}^{-2}$. Temperature was kept at $25^{\circ} \mathrm{C}$ in all trials.

\begin{tabular}{lllllllll}
\hline Eukaryote & \multicolumn{2}{l}{ Primary effluent } & & & \multicolumn{5}{c}{ Secondary effluent } \\
\hline EC & 0 min & $5 \mathrm{~min}$ & $20 \mathrm{~min}$ & $60 \mathrm{~min}$ & $0 \mathrm{~min}$ & $5 \mathrm{~min}$ & $20 \mathrm{~min}$ & $60 \mathrm{mi}$ \\
Amoebae & 70 & $<1$ & $<1$ & $<1$ & 597 & 296 & 101 & $<1$ \\
Flagellates & 2190 & 362 & 4 & $<1$ & 1540 & 48 & $<1$ & $<1$ \\
Ciliates & 34 & $<1$ & $<1$ & $<1$ & 798 & 467 & 1 & $<1$ \\
Metazoa & 2 & $<1$ & $<1$ & $<1$ & 29 & 10 & 5 & $<1$ \\
EF pH 3.0 & Raw & $0 \mathrm{~min}$ & $10 \mathrm{~min}$ & $30 \mathrm{~min}$ & $\mathrm{Raw}$ & $0 \mathrm{~min}$ & $10 \mathrm{~min}$ & $30 \mathrm{mi}$ \\
Amoebae & 3 & 1 & $<1$ & $<1$ & 3540 & 20 & $<1$ & $<1$ \\
Flagellates & 100 & $<1$ & $<1$ & $<1$ & 13,800 & 3480 & $<1$ & $<1$ \\
Ciliates & 17 & 3 & 3 & $<1$ & 476 & 131 & $<1$ & $<1$ \\
Metazoa & 2 & 1 & $<1$ & $<1$ & 12 & 4 & $<1$ & $<1$ \\
EF natural & $0 \mathrm{~min}$ & $5 \mathrm{~min}$ & $10 \mathrm{~min}$ & $30 \mathrm{~min}$ & $0 \mathrm{~min}$ & $5 \mathrm{~min}$ & $10 \mathrm{~min}$ & $30 \mathrm{mi}$ \\
pH & & & & & & & & \\
Amoebae & 3 & 3 & $<1$ & $<1$ & 30 & $<1$ & $<1$ & $<1$ \\
Flagellates & 640 & 620 & $<1$ & $<1$ & 220 & $<1$ & $<1$ & $<1$ \\
Ciliates & 8 & $<1$ & $<1$ & $<1$ & 64 & $<1$ & $<1$ & $<1$ \\
Metazoa & 40 & 40 & 30 & $<1$ & 14 & $<1$ & $<1$ & $<1$ \\
\hline
\end{tabular}

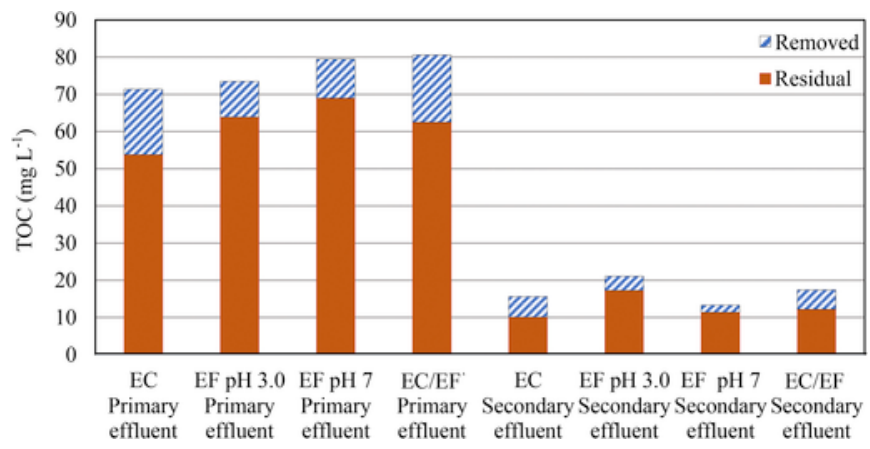

Fig. 2. TOC removed and residual upon different treatments: $\mathrm{EC}$ of $200 \mathrm{~mL}$ of primary and secondary effluents at $j=200 \mathrm{~A} \mathrm{~m}^{-2}$ for $90 \mathrm{~min}$; electro-Fenton (EF) of $100 \mathrm{~mL}$ of the same wastewater samples at $\mathrm{pH} 3.0$ and $\mathrm{pH} 7$ using an undivided BDD/air-diffusion cell (electrodes with $3 \mathrm{~cm}^{2}$ area) at $j=333 \mathrm{~A} \mathrm{~m}^{-2}$ and $25^{\circ} \mathrm{C}$ for $30 \mathrm{~min}$; two-step $\mathrm{EC} / \mathrm{EF}$ processes for $30 \mathrm{~min}$ each.

been reported as well. The quick reduction for somatic coliphages agrees with the results of Zhu et al. (2005) for MS2, a kind of coliphage, spiked into simulated natural water and treated by EC and membrane microfiltration.

\subsection{Electro-Fenton at $\mathrm{pH} 3.0$}

Urban wastewater was then treated by a technology of transformation like EF, firstly at its theoretically optimum $\mathrm{pH}$ of 3.0 , with addition of $0.25 \mathrm{mM} \mathrm{Fe}^{2+}$. To do this, the $\mathrm{pH}$ of the primary and secondary effluents was adjusted with an inert acid like $\mathrm{HClO}_{4}$ to preserve the content of reactive $\mathrm{SO}_{4}{ }^{2-}$ and $\mathrm{Cl}^{-}$ions. The assays were made with $100 \mathrm{~mL}$ of each effluent using a stirred BDD/air-diffusion cell at $j=333 \mathrm{~A} \mathrm{~m}^{-2}$ for $30 \mathrm{~min}$. Microbial quantifications were carried out for the raw samples before acidification as well as for conditioned ones ( $\mathrm{pH}=3.0$ and $\mathrm{Fe}^{2+}$ addition) to discard any substantial effect of pre-electrolysis steps. In these trials, the $\mathrm{pH}$ of both kinds of wastewater dropped up to $2.79 \pm 0.13$, suggesting the formation of acidic products from organic matter (Sirés et al., 2014). However, Fig. 2 illustrates the occurrence of a very low TOC abatement of $9.6 \mathrm{mg} \mathrm{L}^{-1}\left(13.1 \%\right.$ of the initial $\left.73.5 \mathrm{mg} \mathrm{L}^{-1}\right)$ for the primary effluent and $3.8 \mathrm{mg} \mathrm{L}^{-1}\left(18.0 \%\right.$ of the initial $\left.21.1 \mathrm{mg} \mathrm{L}^{-1}\right)$. A lower decontamination was then achieved by EF compared to EC, where the or- ganic matter was separated from the effluent by entrapment on iron hydroxides. This means that urban wastewater contained very recalcitrant organic pollutants that were very slowly destroyed and mineralized by oxidants like $\mathrm{H}_{2} \mathrm{O}_{2}, \mathrm{BDD}\left({ }^{\circ} \mathrm{OH}\right),{ }^{\circ} \mathrm{OH}, \mathrm{S}_{2} \mathrm{O}_{8}{ }^{2-}$ and active chlorine formed from Reactions (4)-(9).

Fig. $3 \mathrm{a}$ and $\mathrm{b}$ shows the decrease of microbiota concentration by $\mathrm{EF}$ at $\mathrm{pH} 3.0$ in both aqueous matrices, which became much more effective than the corresponding EC treatments (see Fig. 1a and b). This can be related to the different inactivation mechanisms in both processes, involving the lysis of the cell walls caused by the attack of the generated oxidizing species in EF (Bruguera-Casamada et al., $2016,2017)$ instead of the entrapment of cells onto the flocs produced in the previous EC cell. Note that direct killing of cells by the electrical field applied is also feasible (Ghernaout, 2017). Note also that under $\mathrm{EF}$ conditions at $\mathrm{pH} 3.0$, no flocs of iron hydroxides are formed and no microbiota coagulation takes place. After $30 \mathrm{~min}$ of $\mathrm{EF}$, for example, the concentration of heterotrophic bacteria was below $10 \mathrm{CFU} \mathrm{mL} \mathrm{m}^{-1}$, with decays of 3.62 and $3.97 \mathrm{log}$ units for the primary and secondary effluent, respectively. Fig. S2 highlights certain effect of acidic conditions ( $\mathrm{pH}$ 3.0) on heterotrophic bacteria since control tests without current supply showed an inactivation of about $1.20 \pm 0.06 \log$ units for both samples. This value was much lower than the one reached in EF process, thus corroborating the important role of inactivation with generated oxidants. In contrast to the apparently analogous behavior of microorganisms in both water matrices found in EC (see Fig. S1), Fig. S2 shows a quicker disappearance of heterotrophic bacteria in the secondary effluent. This trend can be accounted for by the smaller organic load of that wastewater, which therefore enhances the attack of oxidizing species over the microbiota since they are produced at similar rate in both samples operating at the same $j=333 \mathrm{~A} \mathrm{~m}^{-2}$.

Fig. 3a and b depicts the total inactivation of enterococci and somatic coliphages, always in less than $10 \mathrm{~min}$. Similarly, E. coli was completely inactivated in the secondary effluent, whereas it persisted longer time in the primary one although it was already inactive at $30 \mathrm{~min}$. As in the case of EC, the most resistant microorganisms were the $C$. perfringens spores in both EF trials. Worth noting, greater decays of 2.10 and $1.60 \mathrm{log}$ units were obtained for the treatment of primary and secondary effluents, respectively.

The above trends agree with those described by Durán Moreno et al. (2004) for the inactivation of $E$. coli by EF using sewage water. Nevertheless, our results are better to those reported by Aziz et al. (2013), who only found a 3-log units drop of coliform content from landfill leachate by EF.

On the other hand, a look at Table 1 allows inferring a very substantial effect of acidic $\mathrm{pH}$ on the eukaryotic community. A comparison between the two raw effluents and the two conditioned ones informs about a survival $<50 \%$ in all cases. Among ciliates, only Peritrichia belonging to the genera Opercularia and Vorticellides survived, whereas persistent metazoa were rotifers belonging to different groups present in the control with Philodinidae in the primary effluent and some Lecanidae in the secondary one. Finally, a drastic inactivation of all eukaryotes after 10 min of EF can be observed in Table 1, with the exception of the ciliate Opercularia microdiscum. Note that this microorganism belongs to a genus of ciliates with high resistance to stress conditions caused by toxics in activated sludge processes (Madoni, 1994).

\subsection{Electro-Fenton at natural $\mathrm{pH}$}

The EF process is expected to be optimal at $\mathrm{pH} 3.0$ because it produces the highest quantity of the strong oxidant ${ }^{\circ} \mathrm{OH}$ from Fenton's 
a

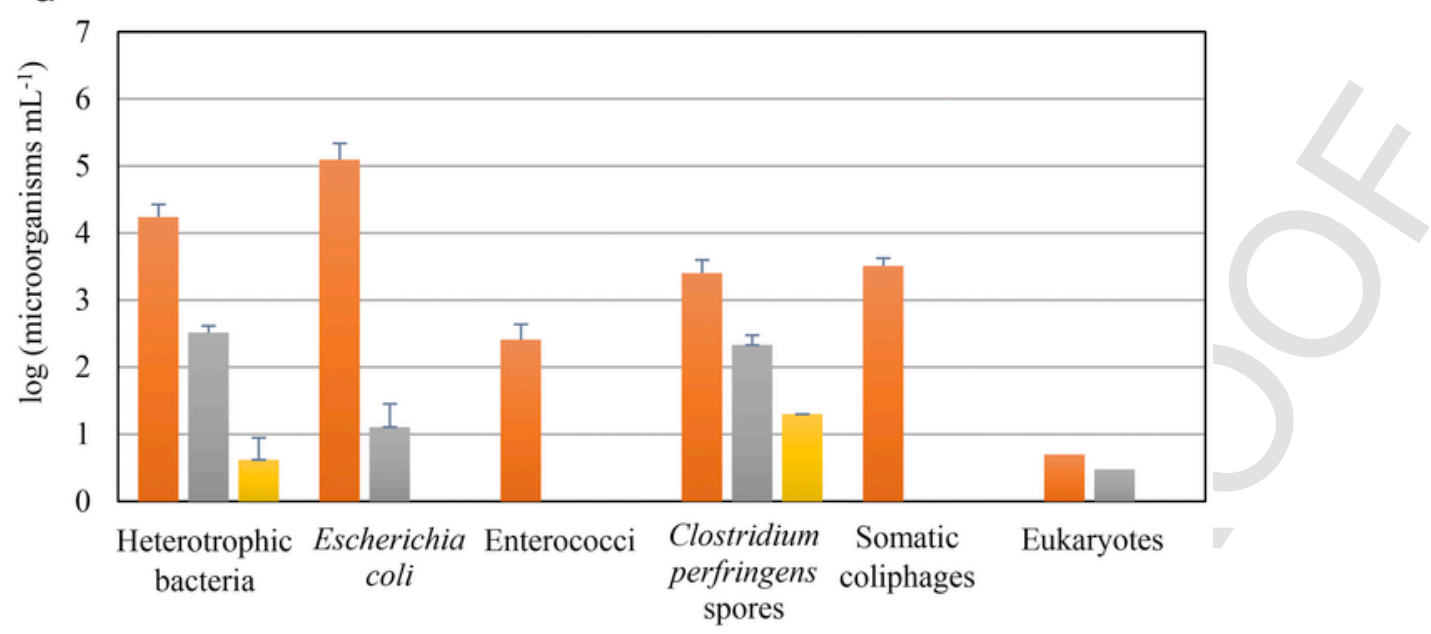

b

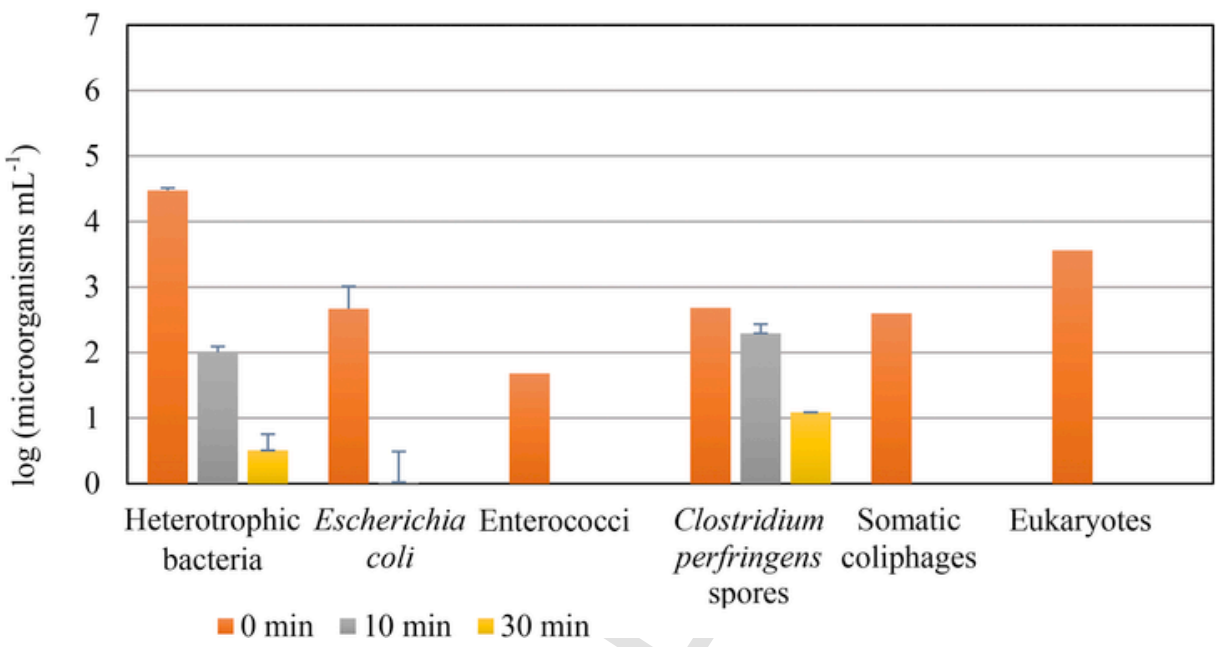

Fig. 3. Change of the logarithm of the concentration of the same microorganisms of Fig. 1 along 30 min of EF treatment of $100 \mathrm{~mL}$ of (a) primary and (b) secondary effluents at pH 3.0 and $j=333 \mathrm{~A} \mathrm{~m}^{-2}$.

Reaction (5) (Sirés et al., 2014; Brillas and Martínez-Huitle, 2015). Nevertheless, although a lower amount of ${ }^{\circ} \mathrm{OH}$ is generated at eco-friendly near-neutral $\mathrm{pH}$, the disinfection role of the other oxidants like $\mathrm{H}_{2} \mathrm{O}_{2}, \mathrm{BDD}\left({ }^{\circ} \mathrm{OH}\right), \mathrm{S}_{2} \mathrm{O}_{8}{ }^{2-}$ and active chlorine, along with iron hydroxides formed at $\mathrm{pH} \sim 7$, may be sufficient. The main aim of this approach was to draw conclusions for further use of the process in a two-step treatment of urban wastewater, as will be discussed in section 3.4.

The EF treatments of $100 \mathrm{~mL}$ of the primary and secondary effluents were carried out at natural $\mathrm{pH}$ under the same conditions described at $\mathrm{pH} 3.0$, i.e., after addition of $0.25 \mathrm{mM} \mathrm{Fe}^{2+}$ in a stirred $\mathrm{BDD} /$ air-diffusion cell operated at $j=333 \mathrm{~A} \mathrm{~m}^{-2}$ for $30 \mathrm{~min}$. In these cases, the $\mathrm{Fe}^{2+}$ content was hardly soluble at the initial $\mathrm{pH}$ of $7.18 \pm 0.07$, which slightly increased up to $7.39 \pm 0.19$. No substantial variation in conductivity of $2.70 \pm 0.25 \mathrm{mS} \mathrm{cm}^{-1}$ was observed. The data of Fig. 2 corroborate the decontamination ability of EF at near-neutral $\mathrm{pH}$, with final TOC removal of $10.5 \mathrm{mg} \mathrm{L}^{-1}(13.2 \%$ of the initial $79.5 \mathrm{mg} \mathrm{L}^{-1}$ ) for the primary effluent and $1.9 \mathrm{mg} \mathrm{L}^{-1}$ (14.2\% of the initial $13.3 \mathrm{mg} \mathrm{L}^{-1}$ ) for the secondary one. Similar TOC abatement was then achieved at $\mathrm{pH} 3.0$ and neutral $\mathrm{pH}$, suggest- ing that oxidants like active chlorine can play an important role in EF regardless of the solution $\mathrm{pH}$ (Thiam et al., 2015; Steter et al., 2016).

Fig. $4 \mathrm{a}$ and $\mathrm{b}$ depicts the excellent disinfection power of EF at neutral $\mathrm{pH}$, giving rise to a remarkable decrease of the content of all microorganisms contained in the two wastewater samples. After $30 \mathrm{~min}$ of treatment, the heterotrophic bacteria concentration diminished 4.12 $\log$ units in the primary effluent and $3.20 \mathrm{log}$ units in the secondary one. Note that in the former case, the decay was even superior to that obtained by EC and EF at $\mathrm{pH}$ 3.0. The decay profile of these bacteria shown in Fig. S3 demonstrates the large effect of the electrolysis during the first $10 \mathrm{~min}$, whereupon the disappearance was strongly decelerated. The enhanced abatement found in the primary wastewater matrix is noteworthy since it is contrary to the behavior obtained in $\mathrm{EF}$ at $\mathrm{pH} 3.0$ (see Fig. S2). This behavior suggests that, apart from the important oxidative action of active chlorine that accounts for a large inactivation, as pointed out above, the formation of iron hydroxides at neutral $\mathrm{pH}$ has a key role as well. As mentioned in section 3.1, coagulation with such hydroxides is more effective for the primary wastewater due to the larger TOC content, with ability to be precipitated and entrap the microorganisms. The formation of such precipitate counteracts the lower generation of ${ }^{\circ} \mathrm{OH}$, leading to a superior performance of $\mathrm{EF}$ at $\mathrm{pH} \sim 7$ compared to that at $\mathrm{pH} 3.0$. 
a

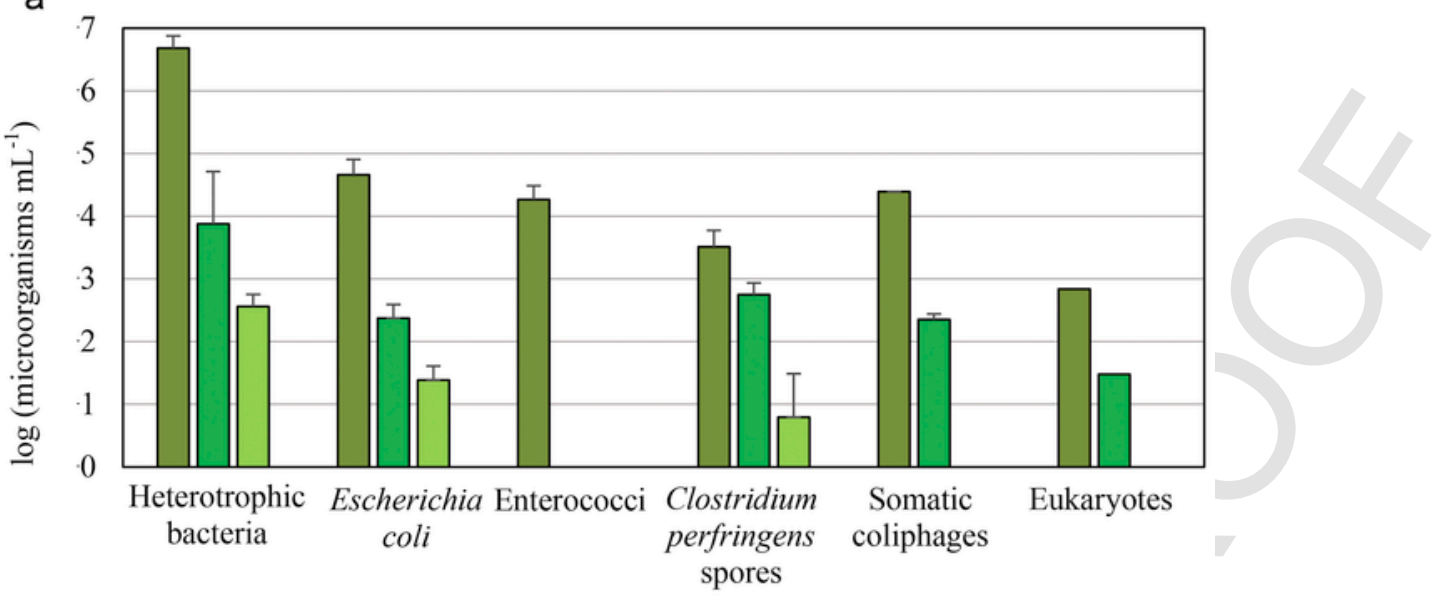

b

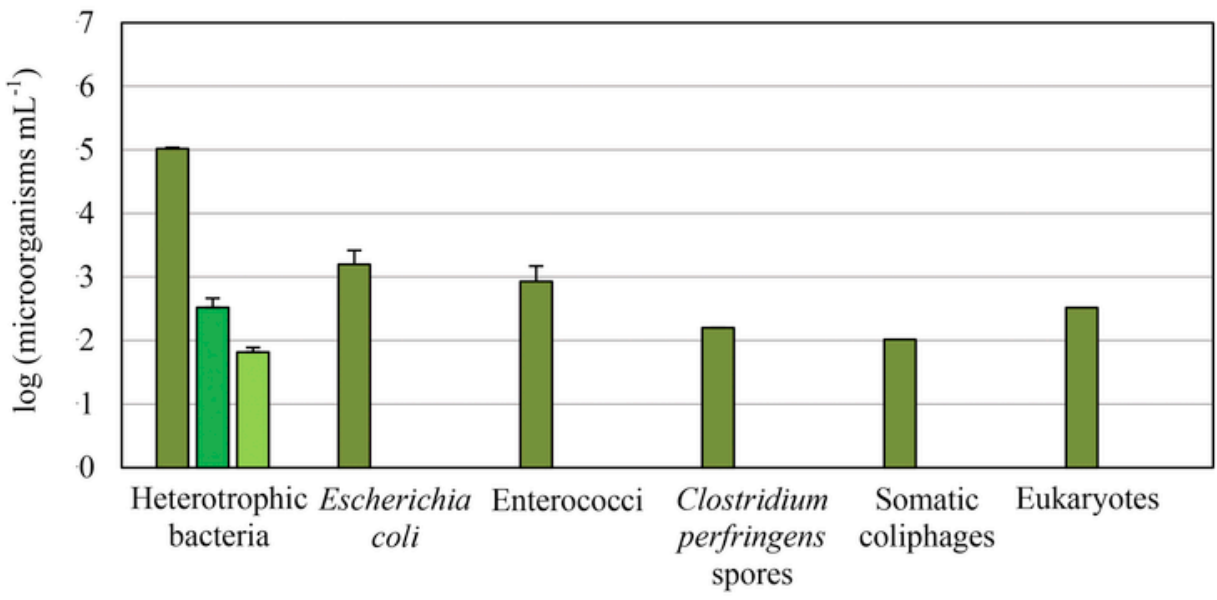

$\square 0 \mathrm{~min} \quad \square 10 \mathrm{~min} \quad \square 30 \mathrm{~min}$

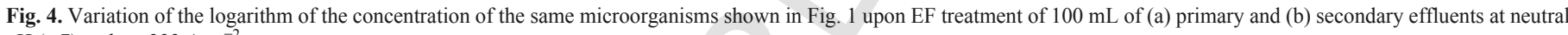
$\mathrm{pH}(\sim 7)$ and $j=333 \mathrm{~A} \mathrm{~m}^{-2}$.

Fig. 4a also shows the rapid and total disappearance of enterococci and somatic coliphages in the primary effluent, being the most sensitive microbiota as found in $\mathrm{EC}$ and $\mathrm{EF}$ at $\mathrm{pH}$ 3.0. In contrast, E. coli and the spores of sulfite-reducing bacteria persisted at the end of EF at near-neutral $\mathrm{pH}$, as occurs with heterotrophic bacteria, with reductions of 3.27 and $2.72 \log$ units, respectively. A different behavior can be observed in Fig. 4b for the secondary wastewater, where all the microbiota tested completely disappeared in less than $10 \mathrm{~min}$, probably because of their much lower concentration compared to that in the primary effluent. These results were much better than those found by EC (see Fig. 1b) and EF at pH 3.0 (see Fig. 3b).

The data of Table 1 for EF at near-neutral $\mathrm{pH}$ reveal a total decay of the eukaryotic community in less of 5 min for the secondary effluent. In contrast, most of the eukaryote bacteria persisted until 5-10 min for the primary one. In particular, high contents of flagellates were detected at $5 \mathrm{~min}$, which belonged to two groups of $E \mathbf{~}$ glenozoa, the euglenidae bodonidae. In the case of metazoa, the nematodes were the most resistant for $10 \mathrm{~min}$, but they were undetectable at $30 \mathrm{~min}$.

All the above findings indicate that $\mathrm{EF}$ at natural $\mathrm{pH}$ can be effective for the disinfection of urban wastewater, particularly for secondary effluents. From this, the performance of a sequential EC/EF process was investigated for both effluents, as discussed below.

\subsection{Electrocoagulation/electro-Fenton without $\mathrm{pH}$ adjustment}

As shown above, EC has greater ability than EF to remove organic matter, whereas EF is superior to disinfect both effluents. Since the maximum microbial removal observed in EC trials was already attained at 20-60 min, the sequential treatment was performed by selecting a duration of $30 \mathrm{~min}$ for the initial EC step, which was performed with $200 \mathrm{~mL}$ samples using a stirred $\mathrm{Fe} / \mathrm{Fe}$ cell at $j=200 \mathrm{~A}$ $\mathrm{m}^{-2}$. The subsequent EF treatment of $100 \mathrm{~mL}$ of the supernatant liquid, which already contained soluble iron ions formed in EC, usually $<3 \mathrm{mg} \mathrm{L}^{-1}$ (Thiam et al., 2014), was performed for $30 \mathrm{~min}$ as well, using a stirred BDD/air-diffusion tank reactor at $j=333 \mathrm{~A} \mathrm{~m}^{-2}$. In the former step, the $\mathrm{pH}$ of both wastewater samples increased from $7.37 \pm 0.04$ to $8.78 \pm 0.09$, which was adjusted to 7 with $\mathrm{H}_{2} \mathrm{SO}_{4}$ in order to apply $\mathrm{EF}$, ending in a $\mathrm{pH}=6.54 \pm 0.17$. The conductivity of both effluents changed slightly during the sequential treatment, from $2.55 \pm 0.15 \mathrm{mS} \mathrm{cm}^{-1}$ to a final value of $2.72 \pm 0.14 \mathrm{mS} \mathrm{cm}^{-1}$. Somatic coliphages and eukaryotes were not analyzed in these assays because they were the most sensitive microbiota to EC, becoming undetectable at the end of such treatment (see Fig. 1a and b, and Table 1). 
As expected from single treatments discussed above, Fig. 2 evidences a quite poor TOC removal for the sequential EC/EF, with an abatement of $18.1 \mathrm{mg} \mathrm{L}^{-1}\left(22.5 \%\right.$ of the initial $\left.80.6 \mathrm{mg} \mathrm{L}^{-1}\right)$ in the primary effluent and $5.2 \mathrm{mg} \mathrm{L}^{-1}\left(29.9 \%\right.$ of the initial $\left.17.4 \mathrm{mg} \mathrm{L}^{-1}\right)$ in the second one. These values differ from those reported by Lucena et al. (2004), who described a very high TOC abatement of about $90 \%$ for a secondary treatment of urban wastewater with conventional activated sludge, although they reached a very weak disappearance (1.5-2.4 log units) of bacterial indicators.

Fig. 5a and $\mathrm{b}$ illustrates the decay of bacteria concentration at different times of the sequential treatment in both wastewater samples. As can be seen, heterotrophic bacteria, E. coli, enterococci and $C$. perfringens spores still presented some activity at the end of the EC step, but the microorganisms were rapidly inactivated by EF demonstrating that the lysis of cell walls by generated oxidizing species $\left(\mathrm{H}_{2} \mathrm{O}_{2}, \mathrm{BDD}(\mathrm{OH}),{ }^{\circ} \mathrm{OH}, \mathrm{S}_{2} \mathrm{O}_{8}{ }^{2-}\right.$ and active chlorine) became much more effective for bacterial removal than their adhesion to the iron hydroxides originated in EC. It can be noticed that when the $\mathrm{pH}$ of the EC supernatant was adjusted to 7, the content of all the microorganisms seemed to slightly increase, as shown in Fig. 5a and b, as well as in Fig. S4. This behavior confirms the survival of a certain number of bacteria adsorbed onto the sludge, as stated above, being resuspended in the solutions during the acidification process prior to the EF step. In the overall process for the primary and secondary wastewater, reductions of 5.17 and $4.37 \mathrm{log}$ units for heterotrophic bacteria, 5.06 and $3.91 \log$ units for E. coli, 4.61 and $3.60 \log$ units for enterococci, and 3.33 and $2.79 \log$ units for the spores of C. perfringens were obtained, respectively. The three latter were not detected at 30 min of EF, whereas a small content of ca. $100 \mathrm{CFU} \mathrm{mL}^{-1}$ of the former bacteria was determined as maximal after the treatment. Fig. S4 reveals a fast inactivation of heterotrophic bacteria during the $30 \mathrm{~min}$ of the EF step, despite the slight concentration increase upon $\mathrm{pH}$ adjustment to 7 after the EC step. These findings allow concluding that the sequential $\mathrm{EC} / \mathrm{EF}$ process is more effective for disinfection of urban wastewater than single EC and $\mathrm{EF}$ at circumneutral $\mathrm{pH}$, since almost complete inactivation of all the bacteria tested can be attained. The enhancement of the disinfection power of EF after EC suggests that during EC treatment the bacteria membranes are weakened by interaction with the $\mathrm{Fe}(\mathrm{OH})_{\mathrm{n}}$ flocs and the action of oxidants like active chlorine, further favoring the attack of oxidants in EF.

Comparison of the effectiveness of the sequential EC/EF treatment for urban wastewater disinfection with other coupled techniques is difficult due to the different systems and experimental conditions reported in the literature. Cotillas et al. (2013) described an integrated

a

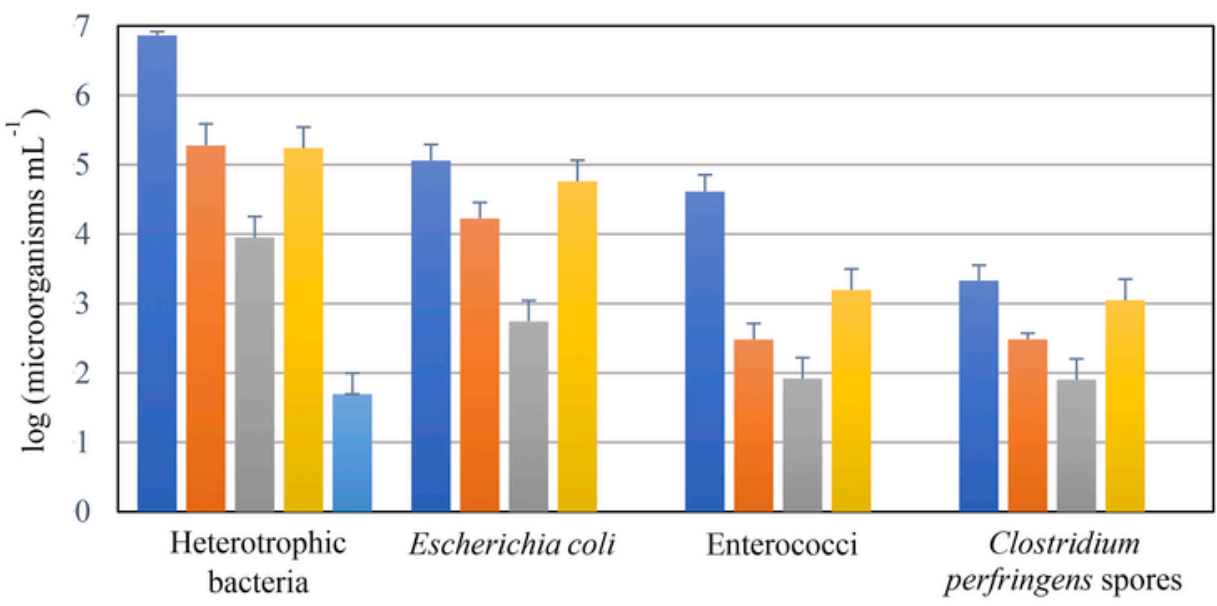

b

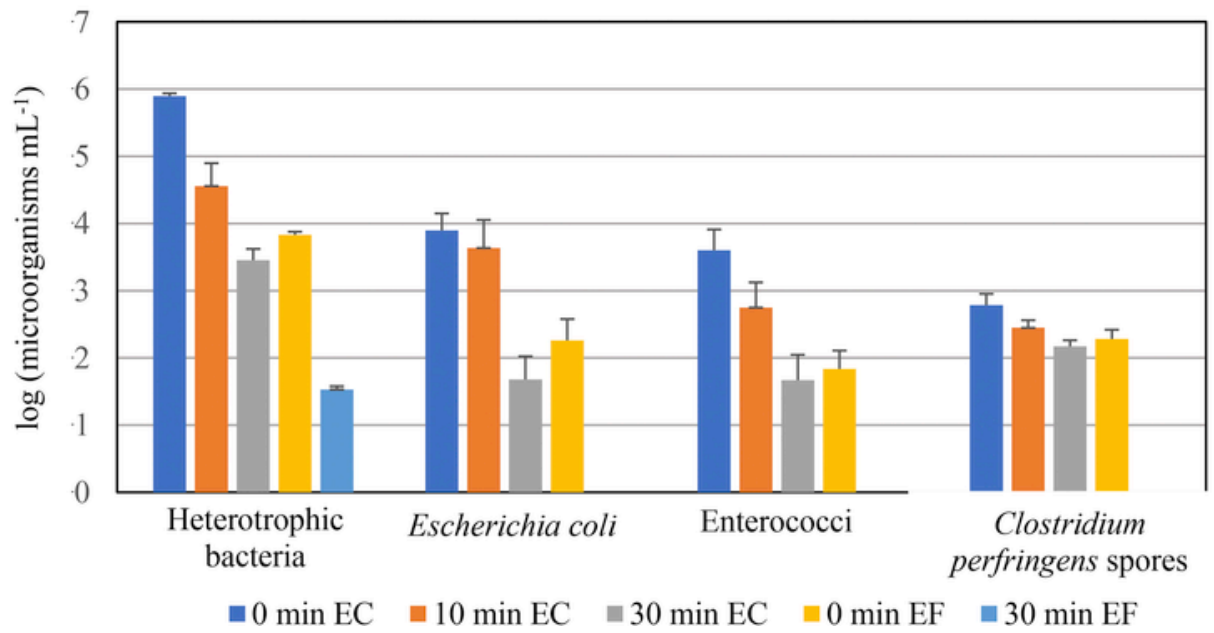

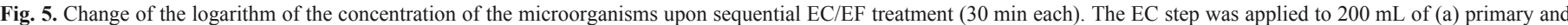
(b) secondary effluents at $j=200 \mathrm{~A} \mathrm{~m}^{-2}$ and $25^{\circ} \mathrm{C}$, being followed by the EF step with $100 \mathrm{~mL}$ of the resulting solution, at $\mathrm{pH} \sim 7$ and $j=333 \mathrm{~A} \mathrm{~m}{ }^{-2}$. 
electrodisinfection/EC cell with ability to reduce at least $4 \log$ units of fecal coliforms from urban wastewater, similarly to our results. In contrast, Barrera-Díaz et al. (2015) integrated EC with $\mathrm{Cu}$ anode and electrochemically generated $\mathrm{H}_{2} \mathrm{O}_{2}$ processes to achieve a discrete reduction of $2 \log$ units of heterotrophic bacteria and E. coli. For a single biological tertiary treatment, Fernandez-Cassi et al. (2016) showed removals of $0.49 \mathrm{log}$ units of heterotrophic bacteria, $2.58 \mathrm{log}$ units of $E$. coli and $1.65 \log$ units of enterococci for a secondary effluent of a lagooning system, which are poorer results than those reported in our study. More contaminant and/or expensive treatments based on chlorine and/or UV irradiation also offer excellent inactivation rates for most microbiota contained in urban wastewater (Montemayor et al., 2008; Souza et al., 2013).

\section{Conclusions}

EC performed with a Fe/Fe cell at $200 \mathrm{~A} \mathrm{~m}^{-2}$ for 90 min caused a slow removal of organic load and abatement of microbiota from urban wastewater treatment plant effluents. The $\mathrm{Fe}(\mathrm{OH})_{\mathrm{n}}$ flocs adsorbed organics and microorganisms, being separated as a sludge where some of those organisms seemed to be still active. Heterotrophic bacteria, $E$. coli, enterococci and $C$. perfringens spores were the most persistent organisms. Higher decrease of microbial content was achieved by EF with a BDD/air-diffusion cell at $\mathrm{pH} 3.0$ and $j=333 \mathrm{~A} \mathrm{~m}^{-2}$, only yielding a very poor TOC abatement. The generated oxidants affected the bacteria walls, causing a large or even total inactivation of all the microbiota in both matrices. EF at circumneutral $\mathrm{pH}$ yielded similar results, with heterotrophic bacteria persisting at the end of electrolysis. The sequential application of EC and EF steps for 30 min each was the best treatment for the disinfection of urban wastewater. All the active microbiota (except the heterotrophic bacteria) were inactivated within 30 min of EF, including the spores. Bacteria membranes were weakened by interaction with $\mathrm{Fe}(\mathrm{OH})_{\mathrm{n}}$ flocs and oxidants in the EC step, further being rapidly affected by the generated oxidants in EF. As the next step, integration of electrochemical technology in current plant units should be made to demonstrate the techno-economic feasibility.

\section{Acknowledgments}

The authors thank financial support under projects CTQ2013-48897-C2-1-R and CTQ2016-78616-R (AEI/FEDER, EU), and from the "Grups de recerca reconeguts" (Generalitat de Catalunya) 2014 SGR 83 and 2014 SGR 914. Support provided by Jaume Cabré plant manager in Aigües de Reus is also acknowledged.

\section{Appendix A. Supplementary data}

Supplementary data related to this article can be found at https:// doi.org/10.1016/j.watres.2017.09.056.

\section{References}

Agulló-Barceló, M., Oliva, F., Lucena, F., 2013. Alternative indicators for monitoring Cryptosporidium oocysts in reclaimed water. Environ. Sci. Pollut. Res. 20 (7), $4448-4454$

Ashbolt, N.J., Grabow, W.O.K., Snozzi, M., 2001. Indicators of microbial water quality. In: Fewtrell, L., Bartram, J. (Eds.), Water Quality: Guidelines, Standards and Health: Assessment of Risk and Risk Management for Water-related Infectious Disease. TJ International (Ltd), Padstow, Cornwall, UK, (Chapter 13).

Aziz, H.A., Othman, O.M., Abu Amr, S.S., 2013. The performance of electro-Fenton oxidation in the removal of coliform bacteria from landfill leachate. Waste Manage 33 (2), 396-400.

Barrera-Díaz, C.E., Frontana-Uribe, B.A., Roa-Morales, G., Bilyeu, B.W., 2015. Reduction of pollutants and disinfection of industrial wastewater by an integrated system of copper electrocoagulation and electrochemically generated hydrogen peroxide. J. Environ. Sci. Health A 50 (4), 406-413.

Barrera-Díaz, C.E., Roa-Morales, G., Balderas Hernández, P., Fernandez-Marchante, P.M., Rodrigo, M.A., 2014. Enhanced electrocoagulation: new approaches to improve the electrochemical process. J. Electrochem. Sci. Eng. 4 (4), 285-296.

Bocos, E., Brillas, E., Sanromán, M.A., Sirés, I., 2016. Electrocoagulation: simply a phase separation technology? The case of bronopol compared to its treatment by EAOPs. Environ. Sci. Technol. 50, 7679-7686.

Brillas, E., Martínez-Huitle, C.A., 2015. Decontamination of wastewaters containing synthetic organic dyes by electrochemical methods. Updat. Rev. Appl. Catal. B Environ 166-167, 603-643.

Bruguera-Casamada, C., Sirés, I., Brillas, E., Araujo, R.M., 2017. Effect of electrogenerated hydroxyl radicals, active chlorine and organic matter on the electrochemical inactivation of Pseudomonas aeruginosa using BDD and dimensionally stable anodes. Sep. Purif. Technol. 178, 224-231.

Bruguera-Casamada, C., Sirés, I., Prieto, M.J., Brillas, E., Araujo, R.M., 2016. The ability of electrochemical oxidation with a BDD anode to inactivate Gram-negative and Gram-positive bacteria in low conductivity sulfate medium. Chemosphere $163,516-524$

Cervero-Aragó, S., Rodríguez-Martínez, S., Puertas-Bennasar, A., Araujo, R.M., Katila, M., Etienne, J., 2015. Effect of common drinking water disinfectants, chlorine and heat, on free legionella and amoebae-associated legionella. PLoS One 10 (8), e0134726.

Cotillas, S., Llanos, J., Cañizares, P., Mateo, S., Rodrigo, M.A., 2013. Optimization of an integrated electrodisinfection/electrocoagulation process with $\mathrm{Al}$ bipolar electrodes for urban wastewater reclamation. Water Res. 47 (5), 1741-1750.

Curds, C.R., Warren, A., Salvadó, H., Roberts, D., 2008. An atlas of ciliated Protozoa commonly found in aerobic sewage-treatment processes. An Aid to Monitor Treatment-Plant Performance Nat. Hist. Mus.

Daghrir, R., Drogui, P., 2013. Coupled electrocoagulation-electro-Fenton for efficient domestic wastewater treatment. Environ. Chem. Lett. 11 (2), 151-156.

Delaire, C., van Genuchten, C.M., Amrose, S.E., Gadgil, A.J., 2016. Bacteria attenuation by iron electrocoagulation governed by interactions between bacterial phosphate groups and $\mathrm{Fe}(\mathrm{III})$ precipitates. Water Res. 103, 74-82.

Durán Moreno, A., Frontana-Uribe, B.A., Ramírez Zamora, R.M., 2004. Electro-Fenton as a feasible advanced treatment process to produce reclaimed water. Water Sci. Technol. 50 (2), 83-90.

El-Ghenymy, A., Centellas, F., Rodríguez, R.M., Cabot, P.L., Garrido, J.A., Sirés, I. Brillas, E., 2015. Comparative use of anodic oxidation, electro-Fenton and photoelectro-Fenton with Pt or boron-doped diamond anode to decolorize and mineralize Malachite Green oxalate dye. Electrochim. Acta 182, 247-256.

Elazzouzi, M., Haboubi, Kh, Elyoubi, M.S., 2017. Electrocoagulation-flocculation as a low-cost process for pollutants removal from urban wastewater. Chem. Eng. Res. Des. 117, 614-626.

Fernandez-Cassi, X., Silvera, C., Cervero-Aragó, S., Rusiñol, M., Latif-Eugeni, F., Bruguera-Casamada, C., Civit, S., Araujo, R.M., Figueras, M.J., Girones, R., Bofill-Mas, S., 2016. Evaluation of the microbiological quality of reclaimed water produced from a lagooning system. Environ. Sci. Pollut. Res. 23 (16), 16816-16833.

Figueras, M.J., Borrego, J.J., 2010. New perspectives in monitoring drinking water microbial quality. Int. J. Environ. Res. Public Health 7 (12), 4179-4202.

Foissner, W., Berger, H., Blatterer, H., Kohmann, F., 1994. Taxonomische und ökologische Revision der Ciliaten des Saprobiensystems. Band III: Hymenostomata, Prostomatida, Nassulida. Bayerischen Landesamtes für Wasserwirtschaft, München, Germany.

Ghernaout, D., 2013. Advanced oxidation phenomena in electrocoagulation process: a myth or a reality?. Desalination Water Treat. 51 (40-42), 7536-7554.

Ghernaout, D., 2017. Microorganisms' electrochemical disinfection phenomena. EC Microbiol. 9 (4), 160-169.

Ghernaout, D., Badis, A., Ghernaout, B., Kellil, A., 2008. Application of electrocoagulation in Escherichia Coli culture and two surface waters. Desalination 219 (1-3), $118-125$.

Ghernaout, D., Ghernaout, B., 2010. From chemical disinfection to electrodisinfection: the obligatory itinerary?. Desalination Water Treat. 16 (1-3), 156-175.

Ghernaout, D., Ghernaout, B., 2012. Sweep flocculation as a second form of charge neutralisation - a review. Desalination Water Treat. 44 (1-3), 15-28.

Ghernaout, D., Naceur, M.W., Aouabed, A., 2011. On the dependence of chlorine by-products generated species formation of the electrode material and applied charge during electrochemical water treatment. Desalination 270 (1-3), 9-22.

Hijnen, W.A.M., Beerendonk, E.F., Medema, G.J., 2006. Inactivation credit of UV radiation for viruses, bacteria and protozoan (oo)cysts in water: a review. Water Res. 40 (1), 3-22.

Lee, J.J., Leedale, G.F., Bradbury, P.C., 2000. An Illustrated Guide to the Protozoa: Organisms Traditionally Referred to as Protozoa, or Newly Discovered Groups, second ed. Society of Protozoologists, Lawrence, Kansas, USA.

Lucena, F., Duran, A.E., Moron, A., Calderon, E., Campos, C., Gantzer, C., Skraber, S., Jofre, J., 2004. Reduction of bacterial indicators and bacteriophages infecting 
faecal bacteria in primary and secondary wastewater treatments. J. Appl. Microbiol. 97 (5), 1069-1076.

Llanos, J., Cotillas, S., Cañizares, P., Rodrigo, M.A., 2017. Electrocoagulation as a key technique in the integrated urban water cycle - a case study in the centre of Spain. Urban Water J. 14 (6), 650-654.

Madoni, P., 1994. A Sludge Biotic Index (SBI) for the evaluation of the biological performance of activated sludge plants based on the microfauna analysis. Water Res. 28 (1), 67-75.

Makwana, A.R., Ahammed, M.M., 2017. Electrocoagulation process for the post-treatment of anaerobically treated urban wastewater. Sep. Purif. Technol. 52 (8), $1412-1422$.

Martínez-Huitle, C.A., Brillas, E., 2008. Electrochemical alternatives for drinking water disinfection. Angew. Chem. Int. Ed. 47 (11), 1998-2005.

Montemayor, M., Costan, A., Lucena, F., Jofre, J., Muñoz, J., Dalmau, E., Mujeriego, R., Sala, L., 2008. The combined performance of UV light and chlorine during reclaimed water disinfection. Water Sci. Technol. 57 (6), 935-940.

Moreira, F.C., Boaventura, R.A.R., Brillas, E., Vilar, V.J.P., 2017. Electrochemical advanced oxidation processes: a review on their application to synthetic and real wastewaters. Appl. Catal. B Environ. 202, 217-261.

Page, F.C., 1988. A New Key to Freshwater and Soil Gymnamoebae: with Instructions for Culture. Freshwater Biological Association, Ambleside, Cumbria, England.

Payment, P., Locas, A., 2011. Pathogens in water: value and limits of correlation with microbial indicators. Ground Water 49 (1), 4-11.

Ricordel, C., Darchen, A., Hadjiev, D., 2010. Electrocoagulation-electroflotation as a surface water treatment for industrial uses. Sep. Purif. Technol. 74 (3), 342-347.

Ricordel, C., Miramon, C., Hadjiev, D., Darchen, A., 2014. Investigations of the mechanism and efficiency of bacteria abatement during electrocoagulation using aluminum electrode. Desalination Water Treat. 52 (28-30), 5380-5389.

Serrano-Suárez, A., Dellundé, J., Salvadó, H., Cervero-Aragó, S., Méndez, J., Canals, O., Blanco, S., Arcas, A., Araujo, R., 2013. Microbial and physicochemical parameters associated with Legionella contamination in hot water recirculation systems. Environ. Sci. Pollut. Res. 20 (8), 5534-5544.
Sirés, I., Brillas, E., Oturan, M.A., Rodrigo, M.A., Panizza, M., 2014. Electrochemical advanced oxidation processes: today and tomorrow. A review. Environ. Sci. Pollut. Res. 21 (14), 8336-8367.

Souza, B.S., Dantas, R.F., Agulló-Barceló, M., Lucena, F., Sans, C., Esplugas, S., De zotti, M., 2013. Evaluation of $\mathrm{UV} / \mathrm{H}_{2} \mathrm{O}_{2}$ for the disinfection and treatment of municipal secondary effluents for water reuse. J. Chem. Technol. Biotechnol. 88 (9), 1697-1706.

Steter, J.R., Brillas, E., Sirés, I., 2016. On the selection of the anode material for the electrochemical removal of methylparaben from different aqueous media. Electrochim. Acta 222, 1464-1474.

Thiam, A., Brillas, E., Centellas, F., Cabot, P.L., Sirés, I., 2015. Electrochemical reactivity of Ponceau 4R (food additive E124) in different electrolytes and batch cells. Electrochim. Acta 173, 523-533.

Thiam, A., Brillas, E., Garrido, J.A., Rodríguez, R.M., Sirés, I., 2016. Routes for the electrochemical degradation of the artificial food azo-colour Ponceau 4R by advanced oxidation processes. Appl. Catal. B Environ. 180, 227-236.

Thiam, A., Zhou, M., Brillas, E., Sirés, I., 2014. Two-step mineralization of Tartrazine solutions: study of parameters and by-products during the coupling of electrocoagulation with electrochemical advanced oxidation processes. Appl. Catal. B Environ. $150-151,116-125$.

United Nations, 2015. Transforming Our World: the 2030 Agenda for Sustainable Development. Resolution A/RES/70/1, Adopted by the General Assembly on $25 \mathrm{Sep}-$ tember 2015.

Valero, P., Verbel, M., Silva-Agredo, J., Mosteo, R., Ormad, M.P., Torres-Palma, R.A., 2017. Electrochemical advanced oxidation processes for Staphylococcus aureus disinfection in municipal WWTP effluents. J. Environ. Manage 198 (1), 256-265.

Zhu, B., Clifford, D.A., Chellam, S., 2005. Comparison of electrocoagulation and chemical coagulation pretreatment for enhanced virus removal using microfiltration membranes. Water Res. 39 (13), 3098-3108. 